Natalia Biłous

\title{
Zapisy mieszczan wołyńskich na rzecz dobroczynności i świątyń różnych wyznań według testamentów z XVII wieku
}

\begin{abstract}
Słowa kluczowe: testamenty, legaty religijne, pobożność, mieszczanie, miasta, Wołyń, XVII wiek

Key words: testaments, religious bequests, piety, burghers, towns, Volhynia, 17 th century

I. Baza źródłowa. II. Testatorzy. III. Miejsca pochówku. IV. Wysokość legatów gotówkowych. V. Legaty w formie ruchomości i nieruchomości.

VI. Legaty na inne cele. VII. Podsumowanie
\end{abstract}

Historycy w Europie Zachodniej i Centralnej od dawna podejmują rozważania nad legatami — zapisami w testamentach na cele dobroczynne i religijne. Przydatność tego typu dokumentów w badaniach nad religijnością i formami praktyk dewocyjnych ukazują prace m.in. powstałe w Wielkiej Brytanii, Francji, Włoszech, Hiszpanii, Niemczech, Austrii i Czechach. W Polsce podobne badania prowadzono aktywnie w ostatnich dziesięcioleciach ${ }^{1}$; to przede wszystkim opracowania Andrzeja Karpińskiego ${ }^{2}$, Rafała Kubickiego ${ }^{3}$, Piotra Olińskiego ${ }^{4}$, Elżbiety Piwowarczyk ${ }^{5}$. O roli cerkwi i religii w życiu prawosławnych i unitów oraz ich aktywności na rzecz Kościołów wschodnich pisała Wioletta Zielecka-Mikołajczyk ${ }^{6}$. Charytatywne poczynania prawosławnych analizował Andrzej Mironowicz ${ }^{7}$, zaś dokonania fundacyjne na podstawie aktów ostatniej woli zbadał Tomasz $\mathrm{Kempa}^{8}$. Na Ukrainie takie badania dla okresu nowożytnego są jeszcze rzadkością, a dotyczą głównie lwowskiej szlachty i Ormian9, elity kozackiej w XVIII w. ${ }^{10}$, duchowieństwa kijowskiego ${ }^{11}$, częściowo szlachty i duchowieństwa wołyńskiego ${ }^{12}$.

${ }^{1}$ Szerzej: Piwowarczyk E. 2013, s. 415-430.

${ }^{2}$ Karpinski A. 1989, s. 204-232.

${ }^{3}$ Kubicki R. 2011, s. 7-27.

${ }^{4}$ Oliński P. 2008.

${ }^{5}$ Piwowarczyk E. 2011a, s. 15-34; Piwowarczyk E. 2011b, s. 77-100 i n.

${ }^{6}$ Zielecka-Mikołajczyk W. 2012, s. 70-164.

${ }^{7}$ Mironowicz A. 1999, s. 79-86.

${ }^{8}$ Kempa T. 2001, s. 74-102.

9 Vinnychenko O. 2010, s. 51-65; Vinnychenko O. 2014, s. 73-83; Vinnychenko O. 2017, s. 51-52.

${ }^{10}$ Popruzhna A. 2006, s. 171-175 i n.

${ }^{11}$ Nowak A. 2008, s. 48-62.

${ }_{12}$ Dovbyschenko M. 2008; Yakovenko N. 2012, s. 137-152; Horin S. 2009, s. 19-35 oraz inne. 
Zachowane testamenty mieszczan wołyńskich z XVII w. są pod tym względem prawie nieznane historykom i stanowią cenne źródło do badań nad kulturą religijną i pobożnością mieszczańską tego czasu w dawnej Rzeczypospolitej.

\section{Baza źródłowa}

Podstawę niniejszych rozważań stanowi 140 testamentów mieszkańców miast wołyńskich. Niestety, z różnych powodów, zachowała się tylko niewielka część ksiąg miejskich z tego regionu. Dlatego też prezentowane badania dotyczą tylko kilku ośrodków. Dokumenty te są rozproszone w różnych archiwach Ukrainy, Polski i Białorusi. Większość z nich pochodzi z ośmiu zespołów przechowywanych w Centralnym Państwowym Archiwum Historycznym Ukrainy w Kijowie (dalej cyt.: CPAHUK). Najwięcej zachowało się tam testamentów ołyckich — w sumie 78 (CPAHUK, zespół 1237). Dwie księgi ołyckie znajdują się obecnie również w Polsce, w Bibliotece Kórnickiej. Jedna z nich zawiera tylko trzy testamenty (z 1625 r.). To zapewne niewielka część ze sporządzonych w rzeczywistości dokumentów tego typu, o czym świadczą liczne odwołania i wzmianki w aktach miejskich ołyckich. Można zatem sądzić, że wiele z tych dokumentów nie zachowało się, albo też nie zostały wpisane do ksiąg.

W 13 księgach Dubna wpisano tylko teksty 24 testamentów (CPAHUK, zespół 33). Jedna spośród ksiąg dubieńskich, w której odnotowano pięć aktów ostatniej woli, znajduje się w Narodowym Historycznym Archiwum Białorusi w Mińsku, w zespole „Radziwiłłowie” (zespół 694, opis 7, sygnatura 816). Oprócz tych 29 testamentów z ksiąg miejskich zachowały się też trzy kolejne w aktach grodzkich. W 12 księgach miejskich Kowla powstałych w omawianym czasie zarejestrowano 20 rozporządzeń ostatniej woli (CPAHUK, zespół 35), kilka wpisano również do ksiąg grodzkich włodzimierskich. We Lwowskiej Naukowej Bibliotece im. W. Stefanyka zachowała się jedna księga miasta Równe, w której stwierdzono 26 testamentów z lat 1691-1699. Tylko jedna księga radziecka z okresu 1638-1640 przetrwała z Łucka; zarejestrowano w niej trzy testamenty (CPAHUK, zespół 23).

Brak natomiast ksiąg miejskich z innych powiatowych miast Wołynia — Krzemieńca i Włodzimierza. Kwerenda archiwalna w zespołach prywatnych ośrodków nie dostarczyła zbyt wielu materiałów; odnaleziono tylko trzy testamenty w księgach miejskich Milanowicz (dwa dokumenty z 1650 r. i z 1694 r.) oraz Wyżwy (jeden z 1638 r.), a także pojedyncze, sporządzone w miasteczkach: Klewań, Ostróg, Sokul (Sokol), Turzysk i Zasław. To niewielka liczba źródeł w stosunku do zasobów zachowanych z innych regionów dawnej Rzeczypospolitej. Jest to wynikiem znacznego zniszczenia archiwów miast wołyńskich podczas licznych pożarów i wojen. Większość miejscowości takich archiwaliów w ogóle nie posiada, a istniejące uległy zdekompletowaniu ${ }^{13}$. Z tego powodu zebrany i analizowany tu materiał jest fragmentaryczny, a chronologicznie dotyczy przeważnie drugiej połowy XVII stulecia. Z tego czasu pochodzi większość, bo 117, tj. 83\% odnalezionych źródeł. Dlatego też prezentowane wnioski należy traktować z pewną ostrożnością.

Formularz uwzględnionych testamentów zawiera na ogół wszystkie zasadnicze elementy dokumentu: invocatio, intitulatio, arenga, dispositio, corroboratio, sanctio, datum, subscriptio. W zasadzie badane akty nie odbiegają od formularza ustalonego w Wielkim Księstwie Litewskim i w Koronie Polskiej, poza przypadkami, gdy opuszczono formuły początkowe i końcowe. Niektóre testamenty ograniczają się do dyspozycji majątkowych albo mają wszystkie klauzule, ale użyte w skróconej formie.

\section{Testatorzy}

Cechą charakterystyczną zbiorowości wołyńskich testatorów jest jej różnorodność. To zarówno osoby bogate, jak i biedne, kobiety i mężczyźni, ludzie o różnym poziomie wykształcenia, 
wielu zawodów. Wszyscy, kierując się potrzebą, wyrazili na piśmie swą ostatnią wolę. Grono to (liczące 140 osób) można scharakteryzować według trzech podstawowych kryteriów:

1) pod względem płci — przy czym znacznie rzadziej dysponujemy ostatnią wolą pozostawioną w formie pisemnej przez kobiety — 46 aktów (33\% wszystkich), niż przez mężczyzn $-94(67 \%)$;

2) pod względem profesji — wśród testatorów (tu dane dotyczące tylko mężczyzn) znaleźli się urzędnicy miejscy — 17 osób (18\%), rzemieślnicy — 15 (16\%), kupcy — 5 (5\%) i najliczniejsi ogrodnicy (rolnicy) — 41 (43,6\%), a także osoby nieokreślonych zajęć - 16 (17\%);

3) pod względem religijno-wyznaniowym; w analizowanym gronie dominowali prawosławni - 71 osób (51\%), pozostali to unici - 35 (25\%) i katolicy - 34 (24\%).

Testamenty kobiece zawierają szczegółowe informacje o kondycji majątkowej, religijności i powiązaniach rodzinnych, także z elitą miejską. Odzwierciedlają one w pewnym stopniu losy kobiet, ich stan emocjonalny i sytuację rodzinną.

Kilkunastu testatorów należało do wyróżniającej się miejskiej elity urzędniczej. Było to czterech wójtów - Maciej Treskowski z Kowla, Piotr Bryzel z Korca ${ }^{14}$, Marcin Irszyński z Sokola, Stefan Wyszpolski z Włodzimierza; dwóch landwójtów — Marek Nifanowicz z Kowla i Parfen Gołuzka z Łucka; pięciu rajców — Walenty Żębecki, Hieronim Taniukiewicz i Jarmosz Chomowicz z Ołyki, Samuel Sołtan z Łucka oraz Andrzej Znojowski z Kowla; pięciu ławników — Hrehory Falilejowicz, Hrehory Nietiakiewicz, Łukasz Poźniewicz i Mikołaj Połupanowicz z Ołyki, Stefan Bułhak z Łucka; a także jeden pisarz miejski z Ołyki — Andrzej Łabuński.

Nieliczne z badanych aktów ostatniej woli zostały sporządzone przez kupców zajmujących się obrotem rozmaitymi towarami. Wiadomo, że pochodzący z Ołyki Iwan Miskiewicz (dokument z 1664 r.) handlował olejem, solą i miodem przaśnym ${ }^{15}$. Jacek Leńczyc ze Stryja (1664 r.) ze swym przyjacielem Konstantym sprzedawał noże i odzież ${ }^{16}$, zaś Jakób Dobko z Ołyki zapewne guziki i pasy (1667 r.), a pozostawił po sobie „wozy dwa kowane kupieckie”17. Kupiec ostrogski i dubieński Aleksander Dzusa zarabiał na handlu futrami i suknem $(1667 \text { r. })^{18}$. Natomiast kupiec Iwan Jołtuchowicz pochodzący z Ołyki transportował wozami nieokreślone towary $(1657 \mathrm{r} \text {. })^{19}$.

Swoje testamenty pozostawili też rzemieślnicy reprezentujący kilka branż: odzieżową dwóch kuśnierzy, krawiec, tkacz i szewc, metalową — miecznik i dwaj kowale, budowlaną — szklarz i cieśla, związaną z produkcją żywności — piwowar i młynarz, oraz lecznictwem — chirurg i aptekarz, poza tym jeden był łaziebnikiem.

Liczne grono testatorów stanowiły osoby żyjące z rolnictwa, właściciele folwarków, sadów, pól i łąk. Nie włączono tu szlachty mieszkającej w miastach, wojskowych, ani duchownych, których testamenty również zostały wpisane do ksiąg miejskich wołyńskich ${ }^{20}$.

Wszystkie wyżej wymienione grupy ludności to przedstawiciele najwyższych bądź średnich warstw wołyńskiego mieszczaństwa, osoby prawdopodobnie co najmniej dobrze sytuowane.

13 Szerzej: Biłous N. 2017, s. 8-11.

${ }^{14}$ Piotr Bryzel był wójtem w Korcu, potem mieszkał w Ołyce, gdzie ożenił się po raz drugi i tam spisał swój testament. $Z$ zawodu był chirurgiem.

${ }^{15}$ CPAHUK. Z. 1237, op. 1, sygn. 7, k. 118v-119.

${ }^{16}$ CPAHUK. Z. 1237, op. 1, sygn. 7, k. 121-121v.

${ }^{17}$ CPAHUK. Z. 1237, op. 1, sygn. 7, k. 167v-168.

${ }_{18}$ Kupiec ten żył poza tym z wynajmu nieruchomości oraz z lichwy, CPAHUK. Z. 33, op. 1, sygn. 1, k. 419-420; opublikowane w: Biłous N. 2016, s. 73-79.

${ }^{19}$ Swą ostatnią wolę spisał przebywając w Manaczynie: ,[...] A iż w Manaczynie przy mnie jest dwa koni i z wozami, i z towarami, tedy ten towar daje do wiernych rąk dla spieniężenia Jackowi Serkizowemu, zięciowi sąsiadowi swemu, jako mu Pan Bóg mił aby to spieniężył, a małżonce mej aby pieniędzy oddał", CPAHUK. Z. 1237 , op. 1, sygn. 4, k. 67-68.

${ }^{20}$ Zob.: Biłous N. 2017, s. 17-21. 
Uwzględnione akty ostatniej woli spisali i uwierzytelnili także ubodzy. Były to dwie kobiety z Ołyki, które pozostawiły skromny dobytek - Matiaszowa Szewelina (1665 r.) ${ }^{21}$ oraz „Maryna, babka w szpitalu Świętego Krzyża" (1684 r.) $)^{22}$.

\section{Miejsca pochówku}

Dokonując zapisów na rzecz kościołów testatorzy wołyńscy uwzględniali przede wszystkim opłaty za msze i za uroczystości pogrzebowe. Dyspozycje funeralne wyznawców prawosławia i unitów nie różniły się zbytnio od rozporządzeń katolików. Wiele z nich zawierało pewne elementy pompa funebris bądź pogrzebowej ascezy. Różnica widoczna jest w przewidzianej liczbie mszy za zbawienie duszy. Często wymieniano także preferowane miejsce wiecznego spoczynku. W tej kwestii wybór kościoła parafialnego uważano za naturalny, natomiast bogatsi mieszczanie, odstępując od tej praktyki, kierowali się np. względami osobistymi lub prestiżowymi.

W Ołyce zaobserwowano wyraźne zróżnicowanie. Mieszczan-katolików, którzy mieszkali przeważnie w centrum miasta, chowano na cmentarzu przy starym kościele św. Piotra (zbudowanym w 1460 r.), a zamożniejszych przy kolegiacie św. Trójcy (wzniesionej w latach 1630-1640) ${ }^{23}$. Były wójt korecki i chirurg ołycki Piotr Bryzel zapisał „do Różańca świętego na aniwersarz za duszę" w tym kościele 100 zł oraz 400 zł na pogrzeb, który miał zorganizować jego „dobrodziej” i patron — pan Samuel Leszczyński, wojewodzic derpski, oboźny koronny i starosta łucki ${ }^{24}$. Zdarzało się, że również osoby mniej zamożne chciały być pochowane w tej świątyni. Np. Stanisław Miedziakiewicz prosił spadkobierców o skromny pochówek, aby jego ciało „było złożone w kościele nowym w brackim grobie, bez kosztu [...]. Trumna aby była prosta nie puklasta, z krzyżem na wierzchu malowanym czarnym. Ciało w proste płótno aby owite było" (1657 r. $)^{25}$. Na rzecz tej świątyni Samuel zapisał cztery srebrne łyżki. Polecił córkom, żeby zamówiły wykonanie z nich dwóch tabliczek wotywnych, zaznaczając, aby ,jedną oddać do obrazu Panny Przena[j]świętrzej Różańca Świętego, a drugą do obrazu Józepha Świętego"26. Prawosławni w Ołyce na ogół wybierali na swój wieczny spoczynek cmentarz przy cerkwi pod wezwaniem Spotkania Pańskiego na przedmieściu Zalesocze, ale również przy unickiej cerkwi św. Trójcy, położonej na przedmieściu Zawrocie. Jewdoksia Iwanowa Kapitanicha zapisała tej cerkwi niezasiane pole — „dninę"27, drugie zaś przeznaczyła miejscowemu protopopowi, żeby pochował jej ciało, wpisał w sobotnik ${ }^{28}$ oraz odprawił 40 mszy za jej duszę (sorokoust ${ }^{29}$ ) $(1666 \text { r. })^{30}$. Stara wdowa Jeuchymka Jośkowa Łukjanowiczowa, chciała być pochowana według

${ }^{21}$ CPAHUK. Z. 1237, op. 1, sygn. 7, k. 135v.

22 CPAHUK. Z. 1237, op. 1, sygn. 1, k. 13.

23 Świątynia uznawana była za najpiękniejszy kościół polski na Wołyniu. Zbudowana została kosztem księcia Albrychta Stanisława Radziwiłła. W roku 1641 uzyskała godność kolegiaty. W 1638 r. przy kościele utworzono seminarium duchowne i szkołę akademicką - filię Akademii Zamojskiej, gdzie pięciu profesorów wykładało logikę, retorykę, gramatykę, teologię i sztuki wyzwolone. W 1640 r. założono szpital oraz fundusz dla 12 ubogich panienek. Od roku 2013 trwają prace restauratorsko-konserwatorskie kosztem Fundacji Dziedzictwa Kulturowego Polski.

${ }^{24}$ CPAHUK. Z. 1237, op. 1, sygn. 7, k. 131v.

${ }^{25}$ CPAHUK. Z. 1237, op. 1, sygn. 4, k. 64v. Testator przede wszystkim zatroszczył się o swoje dzieci, którym zapisał wszystkie nieruchomości i mobilia.

${ }^{26}$ CPAHUK. Z. 1237, op. 1, sygn. 4, k. 65.

27 „Dnina” pola (staropol.) — kawałek pola, który można było obrobić w ciągu jednego dnia pracy.

28 Sobotnik (ukr. синодик, пом'яник) — rękopiśmienna księga, w której zostały zapisane imiona zmarłych dla ich upamiętnienia podczas mszy w kościele prawosławnym (zob.: Timoszenko L. 2011, vyp. 14-15, s. 123).

${ }_{29}$ Sorokoust (ukr., ros. сорокоусm) — rodzaj modlitwy w Cerkwi prawosławnej odmawianej codziennie przez 40 dni w intencji zmarłego lub osoby ciężko chorej.

${ }^{30}$ CPAHUK. Z. 33, op. 1, sygn. 1, k. 153. 
obrzędu religii greckiej przy cerkwi św. Trójcy, blisko zięcia (1670 r.). Wyraziła życzenie odnośnie do organizacji ceremonii, aby była „,piękna”, oraz aby wzięły w niej udział trzy cechy, „w kościele [żeby wtedy - N.B.] dzwonili”, a spadkobiercy modlili się za nią. Na swój pochówek przeznaczyła 5 zł oraz kielich ze srebra o pojemności kwarty, zastawiony za 5 zł, który nakazała w tym celu wykupić i sprzedać ${ }^{31}$. Unitów mieszkających w średnim mieście i na przedmieściu ołyckim Zawrocie chowano również na nekropolii wokół miejscowej cerkwi.

Zapisy testamentalne wskazują, że koszty pogrzebu często mieli ponieść współmałżonkowie, „według możności swej z dóbr wszystkich”. I tak, Stefan Łotoszyński prosił swą żonę, by pochowała go „po chrześcijańsku” na Zawrociu, w cerkwi Trójcy Przenajświętszej, w kupionej przez nią trumnie (1660 r.). Cerkwi tej ofiarował 15 zł i tyle samo ojcu Bazylemu Zalińskiemu, protopopowi ołyckiemu ${ }^{32}$. Ołycki kupiec Iwan Miskiewicz ograniczył się do wyrażenia życzenia skierowanego do małżonki odnośnie do miejsca swego przyszłego pochówku (przy cerkwi unickiej Trójcy Przenajświętszej); nie wydzielił natomiast żadnych funduszy na ten cel (1664) ${ }^{33}$. Ponieważ kupiec Jacek Leńczyca ze Stryja umierał w Ołyce, gdzie został postrzelony, zapewne nie chcąc obarczać rodziny obowiązkiem organizacji pogrzebu, prosił o to swego towarzysza. Miała to być uroczystość urządzona „,według możności”, ale za kwotę 3 zł. Tyleż samo testator asygnował kapłanowi na msze za swą duszę. Jacek chciał zaznać wiecznego spoczynku na nekropolii przy ołyckiej cerkwi (1664 r.) $)^{34}$.

Unici i prawosławni z innych miast wołyńskich swoje groby chcieli mieć na cmentarzach przy lokalnych kościołach parafialnych, którym zapisywali pewne sumy w gotówce, nieruchomości oraz rozmaite mobilia. Mieszczka dubieńska Katarzyna Illaszowa Tołoczkowa, mieszkająca na przedmieściu Surmicze, chciała być pochowana zgodnie z obrządkiem chrześcijańskim blisko miejscowej cerkwi św. Jerzego. Świątyni tej przekazała 5 zł, analogiczną kwotę zapisała duchownemu za odprawienie nabożeństwa za jej duszę (1664 r.) ${ }^{35}$. Ciężko chora Maria Seńkowna sporządziła swój testament w obecności spowiednika — ojca Dionizego Korbusowicza z cerkwi św. Mikołaja i dwóch urzędników miejskich. Testatorka zdecydowała, by jej ciało złożono przy tejże cerkwi, na rzecz której zapisała 20 zł, na wypominki przekazała kwotę 10 zł, zaś na szpitale polski i ruski po 5 zł (1645 r. $)^{36}$. Prawosławny Parfen Hołuzka, były landwójt i pisarz wójtowski z Łucka, zdecydował zaś: „A ciało moje grzeszne, jeśliby Pan Bóg posłał czas rozłączenia mego tu w Łucku przy cerkwi świętej Trójcy małżonka moja miła, pani Fedora Hołuzkowa, ma ućciwie według zakonu i wiary świętej wschodniej cerkwi greckiej, w której urodził się i do tego czasu w niej to mam, i wedle dostatku mego chudego do grobu odprowadzić i pochować ma" (1628 r.) $)^{37}$.

W testamentach mieszczan z Równego brak wzmianek o miejscu pochówku oraz o darowiznach na cele pobożne. Testatorzy tylko zaznaczali, że we wszystkim zdają się na swoich spadkobierców (krewnych albo dzieci) i proszą jedynie o pogrzeb zgodnie z obyczajem chrześcijańskim. Prawdopodobnie wynikało to z faktu, że prawosławie było tam wyznaniem dominującym $^{38}$. Lakoniczność aktów ostatniej woli, w tym brak zapisów na uroczystości funeralne, msze zaduszne i inne cele pobożne, jest charakterystyczna także dla testamentów powstałych

${ }^{31}$ CPAHUK. Z. 1237, op. 1, sygn. 7, k. 197.

${ }^{32}$ CPAHUK. Z. 1237, op. 1, sygn. 7, k. 38.

${ }^{33}$ CPAHUK. Z. 1237, op. 1, sygn. 7, k. 118v.

${ }^{34}$ CPAHUK. Z. 1237, op. 1, sygn. 7, k. 121-121v.

${ }^{35}$ CPAHUK. Z. 33, op. 1, sygn. 1, k. 283.

${ }^{36}$ CPAHUK. Z. 33, op. 1, sygn. 6, k. 16-16v.

${ }^{37}$ CPAHUK. Z. 25 , op. 1, sygn. 160 , k. $1647 \mathrm{v}$.

${ }^{38}$ LNNB, z. 91, sygn. 44. 
w innych ośrodkach miejskich Rzeczypospolitej. Np. w Przemyślu dyspozycje dotyczące organizacji pogrzebu zawarte były jedynie w 45,7\% takich dokumentów ${ }^{39}$.

\section{Wysokość legatów gotówkowych}

Jedną z form legatów pobożnych były zapisy gotówkowe przeznaczane na odprawienie mszy za duszę, na rzecz kościołów, szpitali, bractw religijnych i ubogich. Zdaniem Krzysztofa Mrozowskiego trudno stwierdzić, czy testatorzy starali się w ten sposób zapewnić sobie zbawienie, czy też w takiej formie wyrażali przywiązanie do konkretnych miejsc i wartości ${ }^{40}$.

Można stwierdzić, że to możliwości finansowe poszczególnych osób determinowały wysokość zapisów gotówkowych oraz ich liczbę. Najczęściej testatorzy wspierali od jednej do trzech instytucji, a cztery i więcej obdarowały tylko trzy osoby. Dyspozycje pobożne mieszczan wołyńskich wyznawców katolicyzmu stanowiły przeważnie niewielkie kwoty - 5-10 zł, tylko zamożniejsi legowali większe sumy. Aptekarz królewski, Wojciech Mścisławowicz, mieszkający przed śmiercią w Łucku (testament z 1632 r.), prosił o pochówek w podziemiach tamtejszego kościoła oo. Jezuitów, przy zmarłych dzieciach, legując na rzecz tej świątyni $150 \mathrm{zł}$. Ofiarował również temu kościołowi „ołtarzyk z reliquiami świętych”, żeby każdego roku odprawiano za jego duszę aniwersarz. Oprócz tego Wojciech dokonał zapisów na rzecz innych instytucji religijnych w mieście: dla klasztoru brygidek — 150 zł, dla szpitala św. Łazarza — 30 zł i ogród, zaś dla ojców dominikanów - 50 zł. Mieszczanin zaznaczył w testamencie, że nie posiada gotówki, ale ma znaczny dług u Izabeli Siemaszkowej ze Służewa, kasztelanki bracławskiej — w wysokości ponad 500 zł, który przeznaczył na pokrycie wyżej wymienionych legatów ${ }^{41}$. Wójt sokólski Marcin Irszyński, kierując się intencją „ku wiecznej pamięci swej i ku pomoczy duszy", podarował nowo wzniesionemu tam kościołowi 100 zł, a szpitalowi - 150 zł. Natomiast, aby opłacić pochówek, polecił wymłócić 4 kopy jęczmienia i 3 kopy żyta, a ziarno

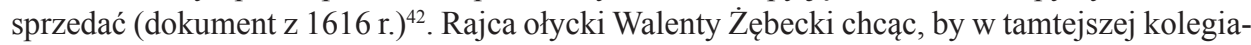
cie odprawiano msze w rocznicę jego śmierci, zapisał w gotówce 200 zł, kolejne 100 zł asygnował na organizację pogrzebu, zaś $30 \mathrm{zł}$ na trycezymę $e^{43}(1654 \text { r. })^{44}$. Mniejszą sumę, tzn. $70 \mathrm{zł}$, przekazał Walenty Szklarz (w 1649 r.) kościołowi ojców bernardynów w Dubnie ${ }^{45}$.

Największe kwoty, łącznie po 300 zł, przeznaczone na rzecz instytucji kościelnych oraz na inne cele religijne i wydatki pogrzebowe legowały dwie zamożne mieszczki z Ołyki — Marianna Słończyna (w 1661 r.) i Zofia Kunowska (w 1667 r.). Zwłaszcza dyspozycje pierwszej z nich są obszerne i dość szczegółowe. Kobieta wyraziła życzenie, aby za 100 zł przygotowano obiad dla kapłanów, którzy będą uczestniczyć w pogrzebie, a za 30 zł posiłek dla ubogich. Obecni podczas uroczystości przedstawiciele cechów mieli otrzymać 7 zł, ubodzy 3 zł, zaś duchowni łącznie 50 zł. Na oprawę muzyczną i dla sług kościelnych Marianna przewidziała sumę 10 zł. Na obicie trumny i zakup białej odzieży pośmiertnej zarezerwowała 30 zł. Jałmużna rozdawana ubogim podczas pogrzebu miała wynieść 3 zł. Poza tym kobieta ofiarowała Bractwu Różańcowemu 30 zł, na „kielich [który — N.B.] bracia powinni sprawić”. Egzekutorami swojej ostatniej woli uczyniła trzech ołyckich księży scholastyka Jana Baptistę Czechowicza, kaznodzieję i ordynariusza Krzysztofa Sideckiego oraz wikarego tamtejszej kolegiaty,

39 Krochmal J. 1989, s. 141.

${ }^{40}$ Mrozowski K. 2010, s. 192.

${ }^{41}$ CPAHUK. Z. 25, op. 1, sygn. 183, k. 1411-1415.

42 CPAHUK. Z. 25, op. 1, sygn. 103, k. 217-219.

43 Trycezyma (staropol.) — msza święta gregoriańska rozumiana jako 30 mszy za duszę zmarłego, odprawiane codziennie, przez kolejne dni po śmierci, za darowanie jej kar w czyśćcu.

${ }^{44}$ CPAHUK. Z. 1237, op. 1, sygn. 4, k. 40-40v.

${ }^{45}$ CPAHUK. Z. 33, op. 1, sygn. 6, k. 40v. 
Andrzeja Chromińskiego. Testatorka prosiła ich, aby zobowiązali kapłana do odprawiania co tydzień mszy świętej za jej duszę. Marianna podkreśliła w dokumencie, że wymienione przez nią darowizny na cele pobożne są wynikiem jej własnych decyzji, niepodważalnych przez dwójkę jej dzieci, obdarowanych sowicie spadkiem po ojcu: „A że syn mój Maxymilian zostaje i córka Jagnieszka, którom wydałam za pana Marcina Cieszkowskiego, tych wcale do tych wzwyż mianowanych summ na pobożne uczynki i na pogrzeb naznaczonych oddalam, iż żadnym prawem nie mogą się do tego interessować, ponieważ ja ich zostawuję przy dobrach ojczystych, na które i ja przez wniesienie posagu mego dziesięć tysięcy wniesionych miała, tych tedy tym respektem, w równy dział dziatkom moim ustępuję, daję, daruję i leguję. Także bydło różne, które inwentarz pokazuję, obiecując to sobie po nich, że będąc wdzięczni dobrodziejstwa macierzyńskiego duszy mej przez pobożne uczynki czynić dobrze nie przepomnią"46.

Bezdzietna, czterokrotnie owdowiała Zofia Kunowska uzyskała po swoich małżonkach znaczne spadki. Duże sumy, którymi dysponowała, zapisała w formie legatów pobożnych. Przy sporządzeniu jej testamentu świadkami byli ksiądz Jan Więckiewicz, wikary kolegiaty i profesor Akademii ołyckiej Jan Bogusz ${ }^{47}$, oraz burmistrz Kasper Sewerycz. Testatorka prosiła, aby pochować jej ciało w „brackim grobie” w miejscowej kolegiacie, której zapisała 100 zł na msze „za duszę tak [...] testatorki, jako też rodziców jej, tudzież małżonków i wszystkich krewnych”. Kolejne 100 zł podzieliła na odprawienie pięciu trycezym w różnych świątyniach, przeznaczając na ten cel po 20 zł: dla kościoła w Ołyce (gdzie Zofia chciała być pochowana), a także dla dominikanów w Łucku, dla bernardynów w Sokalu, dla dominikanów w Podkamieniu oraz dla karmelitów trzewiczkowych w Dorohostajach. Pozostałe 100 zł miało być wydane na odpowiednią oprawę uroczystości funeralnych — „przystojne pochowanie ciała [...] po śmierci”. Poza tym ,żeby mógł bydź i dla ubogich obiad, za duszę testatorki przekazała łyżek srebrnych stołowych dwanaście [...]"48.

Powyższe przykłady stanowią jednak wyjątki. Większość testatorów przewidywała skromny pochówek i legowała małe kwoty albo nie zapisywała żadnych. Np. wdowa Regina Golaszewska prosiła jedynie syna, aby — zgodnie ze swoimi możliwościami — pochował jej ciało na cmentarzu przy ołyckiem kościele św. Piotra, w testamencie nie uwzględniając żadnych środków na ten cel, ani nie czyniąc odpowiednich dyspozycji (1660 r. $)^{49}$. Podobnie postąpiła mieszczka ołycka Dorota Matysowa Sokalska (1649 r. $)^{50}$ oraz Apolonia Łukaszewiczowa z Kowla, mimo że wstępna część jej testamentu (sporządzonego w 1678 r.) dość wyraźnie świadczy o jej głębokiej pobożności ${ }^{51}$.

Zdarzały się również przypadki, gdy zamożni katolicy na mocy aktów ostatniej woli zostawiali cały majątek swoim dzieciom, nie przewidując innych wydatków. Tak uczyniła np.

46 CPAHUK. Z. 1237, op. 1, sygn. 7, k. 91v.

47 Jan Bogusz przede wszystkim był profesorem Akademii Zamojskiej: Joannes Bogusz, Artium et Philosophiae Baccalaureus, Poeseos Professor. Vocatus (1663). Mortuus Jaroslaviae 1671, zob.: Wiadomość. 1899-1900, s. 43.

48 CPAHUK. Z. 1237, op. 1, sygn. 7, k. 158v.

49 CPAHUK. Z. 1237, op. 1, sygn. 7, k. 44v.

${ }^{50}$ CPAHUK. Z. 1237, op. 1, sygn. 4, k. 38-38v.

51 „W imie Trójce Przena[j]świętszej Ojca i Syna, i Ducha Świętego. Amen. / Ja, Appolonia Hawryła Łukaszewicza córka a małżonka sławetnego Kondrata Ławrynowicza, widząc tego świata mizernego niestateczność i nietrwałość, i uważając sententią dekretu Pana Wszechmocnego, którą rodzice nasi u Raju pirwsi, przez przęstąpienie roskazania jego świętego na rodzaj ludzki zaciągnęli, za ukąszeniem jabłka, przez które zaraz ten dekret stanął, tamże w Raju surowy i nigdy nie odmienny że kożdy człowiek tak z największych monarchów, jako z najmniejszych stanów umierać musi, będąc ja od Stworzyciela mego chorobą nawiedzona, i mając ten dekret przed oczyma memi, lub chora na ciele, ale zdrowa na umyśle naprzód duszę moją grzeszną w ręce Twórcy memu oddaję i przenaczystrzej matce jego, prosząc jej pokornie, aby onę z rąk swych świętych synowi swemu najmiłszemu zalecieła, a ciało moje grzeszne poniewasz z zięmie wyszlo do ziemię zaś ono oddaję", CPAHUK. Z. 35, op. 1, sygn. 6, k. 131v. Podobne sformułowania rzadko stosowano w testamentach mieszczan z omawianego regionu. 
ołycka burgrabina, stara wdowa Anna Szymonowa Maryńska, zapisując w swoim testamencie (z 1665 r.) nieruchomości („dom na całym placu w ulicy Szpitalnej z dwiema izbami, piącią piekarniami" i inne) oraz wszystkie rzeczy ruchome trzem synom. Jeden z nich, Anioł Maryński, wstąpił do zakonu św. Franciszka, a w testamencie wzmiankowany był jako gwardian klasztoru w Połocku ${ }^{52}$. Apolonia, wdowa po pisarzu ołyckim Marcinie Bielcu, chorując i chcąc zabezpieczyć potomstwo, sporządziła swój testament siedemnastego dnia po śmierci męża (w 1669 r.). Prosiła, aby synowie - Krzysztof i Mikołaj pochowali ją w grobie brackim przy zmarłym małżonku. Testatorka przekazała im wszystkie należące do niej dobra ${ }^{53}$.

Również prawosławni mieszczanie i unici przeważnie legowali nieduże kwoty w gotówce (w wysokości 5-10 zł), albo przekazywali długi lub czynili zapisy pieniężne, które miały być zrealizowane przez spadkobierców w zamian za ofiarowany im majątek. Dłużników zobowiązywano do przekazania pożyczonych u testatora pieniędzy wskazanej w dokumencie instytucji religijnej lub dobroczynnej. Ławnik ołycki, Łukasz Poźniewicz, mimo że był zamożnym właścicielem nieruchomości, chciał oddać z dóbr ojcowskich tylko 5 zł do skrzynki brackiej w cerkwi, natomiast protopopowi Bazylemu Zalińskiemu używaną przez trzy lata bryczkę, aby ten „miał staranie o duszy jego i o pogrzebie ciała jego bez odprawy wszelkich obiadów” (1669 r.) ${ }^{54}$. Trzykrotnie wyższą sumę na rzecz tej samej świątyni (15 zł) oraz analogiczną dla ojca Zalińskiego przewidział w swoim testamencie Stefan Łotoszyński (w dokumencie z 1660 r.) ${ }^{55}$. Łucki ławnik Stefan Bułhak legował 10 zł cerkwi pod wezwaniem św. Pokrowy (Opieki Matki Bożej), gdzie chciał być pochowany ${ }^{56}$. Przywoływany wcześniej kupiec Aleksander Dzusa (1667 r.) życzył sobie, by pochować go w klasztorze św. Krzyża w Dubnie ${ }^{57}$, któremu legował 20 zł. Obdarował także dwie inne instytucje — klasztor w Milczu (kwotą 20 zł) i szpital ruski w Dubnie (10 zł $)^{58}$. Ołycki mieszczanin Iwan Antypowicz zaznaczył w swoim rozporządzeniu ostatniej woli (z 1658 r.), aby kwotę w wysokości 10 kop litewskich groszy ofiarować tej cerkwi, przy której będzie się znajdować jego grób ${ }^{59}$. Kowelska mieszczka Hasia Chodarzowna zapisała cerkwi wedenowskiej 20 zł ,z domu i ogrodu” ${ }^{\prime 0}$. Wśród prawosławnych mieszczan ołyckich najwięcej przekazał Iwan Wettiuk — 40 zł na cerkiew zalasocką „dla ozdoby jakiej cerkiewnej według porady pp. mieszczan” oraz 20 zł kapłanowi tej cerkwi „tak za pogrzeb, jako też i za duszę jego aby czynił dobrze, żeby więcej ni o co żony jego Maryny nie turbował" (1665 r. $)^{61}$. Rajca Jarmosz Chomowicz polecił żonie Annie Antypowiczownie złożyć jego ciało na cmentarzu obok tej świątyni, ale „według możności”. Testator nie asygnował żadnych kwot na ten cel (1668 r.) ${ }^{62}$. Obciążony licznymi długami kowelski burmistrz, Andrzej Znojowski, nie dokonał zapisów na cele religijne, lecz prosił, by sprzedać jego konia, a za uzyskane w ten sposób fundusze za duszę jego „,według zwyczaju chrześcijańskiego ceremonie odprawić i ciało pogrześć, i wszelaki porządek uczynić mocą i powagą testamentu" (1685 r. $)^{63}$. Mieszkająca w Kowlu Nastazja Aleksandrowa zostawiła w gotówce 9 dukatów i zwracała się z prośbą do opiekunów swego testamentu (z 1671 r.) o odpowiednie rozdysponowanie tej kwoty pomiędzy

52 CPAHUK. Z. 1237, op. 1, sygn. 7, k. 125-125v.

${ }^{53}$ CPAHUK. Z. 1237, op. 1, sygn. 7, k. 188-188v.

54 CPAHUK. Z. 1237, op. 1, sygn. 7, k. 195v.

55 CPAHUK. Z. 1237, op. 1, sygn. 7, k. 38.

56 CPAHUK. Z. 23, op. 1, sygn. 1, k. 92v.

57 Dokładniej o tej świątyni w: Horin S. 2011, s. 133-138.

58 Biłous N. 2016, s. 73-79.

${ }^{59}$ CPAHUK. Z. 1237, op. 1, sygn. 7, k. 46.

${ }^{60}$ CPAHUK. Z. 35, op. 1, sygn. 2, k. 85v.

${ }^{61}$ CPAHUK. Z. 1237, op. 1, sygn. 7, k. 142v.

${ }^{62}$ CPAHUK. Z. 1237, op. 1, sygn. 7, k. 182v.

${ }^{63}$ CPAHUK. Z. 35, op. 1, sygn. 7, k. 233-234v. 
spadkobierców i wydzielenie z tego sumy dla instytucji kościelnych: ,[...] Tych że sławetnych panów urzędowych uprosiłam sobie, aby tych krewnych moich według słuszności podzielili i respekt na domy Boże mieli” ${ }^{\prime 64}$. Fedor Bakoriński zapisał cerkwi w Ołyce 5 zł (w 1644 r. $)^{65}$, zaś 3 zł przekazał jej Harasim Łaziebnik (w 1644 r.) ${ }^{66}$. Zadłużony ławnik Hrehory Falelijowicz nie legował żadnych sum, jedynie prosił swą małżonkę, aby „według przemożenia” pochowała jego ciało przy tej świątyni (1659 r.) ${ }^{67}$. Z kolei kuśnierz Jurko Sereda w swoim testamencie wyraził życzenie, aby jego grób znajdował się przy cerkwi zawrockiej. W swojej ostatniej woli (z 1664 r.) nie przewidział ani kwot na pokrycie kosztów pogrzebu, ani innych związanych ze sferą duchową, mimo iż był osobą zamożną, dysponującą sporymi sumami pieniędzy ${ }^{68}$.

W 1617 r. w Łucku miejscowa szlachta i prawosławni mieszczanie założyli bractwo Podwyższenia Krzyża Pańskiego. Jego członkowie odbudowali w 1619 r. spalony miejscowy szpital, ufundowali też szkołę, cerkiew i klasztor ${ }^{69}$. W 1621 r. burmistrz Samuel Wasilewicz Sołtan, z zawodu kupiec, w swoim testamencie przekazał tej konfraterni 100 zł. Nakazał też sprzedać należący do niego „kramny towar” (sukno, tkaniny srebrne i złote oraz szaty białogłowskie), a otrzymane pieniądze przeznaczyć na wyderkaf, z którego miało być finansowane utrzymanie i nauczanie ubogich oraz zakonników: „na wyderkauf dać, żeby ta suma w całości zostawała, a z uzyskanych z niej pożytków żeby na wychowanie słuszne osobom w szpitalu przy cerkwi brackiej Podwyższenia Krzyża Pańskiego będącym, także biednym uczniom na naukę przychodzącym i zakonnikom tego klasztoru na opatrzenie było, żeby oni za odpuszczenie grzechów moich i za duszę moją Pana Boga błagali ustawicznie, panowie starzy z bractwa uczynić będą powinni"70. Na potrzeby brackiej świątyni ofiarował także dwa place z zabudowaniami oraz oprawiony w srebro stary ewangeliarz ${ }^{71}$. Testator przeznaczył również datki dla trzech innych instytucji kościelnych łuckiej cerkwi Krzyża Świętego ofiarował 15 zł, zaś cerkwiom św. Dmitra i jarowickiej Wniebowstąpienia Chrystusa po 5 zł na sorokoust ${ }^{72}$.

Dość częstą praktyką było zapisywanie legatów w formie pieniędzy, których testatorzy nie mogli odzyskać od swoich dłużników za życia i polecali to uczynić swoim spadkobiercom albo egzekutorom testamentu. Najwięcej osób miało zobowiązania finansowe wobec wspomnianej powyżej, zamieszkałej w Ołyce Marianny Słończyny ${ }^{73}$. Zamożny mieszczanin Iwan Ihnatowicz (1695 r.), będąc bezdzietnym wdowcem, przekazał przed śmiercią sumy dłużne oraz gotówkę (400 zł) na rzecz znajdujących się w Kowlu czterech cerkwi: „Długi zaś moje własne u różnych osób, jako to u sławetnego Theodora Hrehorowicza złotych 120 monety i liczby polskiej spólnie z małżonką jego, na który dług zastawa metal srebrny z figurami z jednej strony Abraham, z drugiej strony trzy krzyże z osobami. U Pawła Dulika złotych 120 za dom cerkiewny, który kosztem i staraniem moim jest zbudowany na gruncie cerkiewnym. Ten tedy dom ma wieczną legacją moją przy cerkwie sobornej zostawać i ktokolwiek będzie mieszkał w nim, powinien

${ }^{64}$ CPAHUK. Z. 35, op. 1, sygn. 4, k. $118 \mathrm{v}$.

${ }^{65}$ CPAHUK. Z. 1237, op. 1, sygn. 4, k. 8.

${ }^{66}$ CPAHUK. Z. 1237, op. 1, sygn. 4, k. 20.

${ }^{67}$ CPAHUK. Z. 1237, op. 1, sygn. 4, k. 91.

${ }^{68}$ CPAHUK. Z. 1237, op. 1, sygn. 7, k. 107v108.

${ }^{69}$ Dokładniej zob.: Arkhiv ukrains'koi tserkvy. 2014, s. 14-150.

${ }^{70}$ CPAHUK. Z. 26, op. 1, sygn. 31, k. 126: на выдєркафъ дати, абы сума тая вся иело завъшє зоставала, а с приходячых з неє пожытковъ жебы выхованє слушнов шпиталнымъ, при чєркви братской Воздвижєния Честнаго Креста будучым, такъ же нищылм школным, на науку приходячым и законником того ж манасътыра и на опатрєнъє было, абы они за одпущєнъе грєховъ моих и за душу мою Господа Бога уставичне просили, панове братство старшыс учынити будут повинни. Tłum. $\mathrm{z}$ oryginalu N. Biłous.

${ }^{71}$ CPAHUK. Z. 26, op. 1, sygn. 31, k. 127.

72 CPAHUK. Z. 26, op. 1, sygn. 31, k. 127.

${ }^{73}$ CPAHUK. Z. 26, op. 1, sygn. 31, k. 91v. 
doroczny czynsz cerkiewnej skrzynce dawać. Jeżeliby zaś pomieniony Paweł nie miał oddać tego długu złotych 120, tedy ten dom wolno komu inszemu przedać, a jemu długu mego winnego powinni opiekunowie z dóbr moich pozostałych zł. 30 oddać [...]”74. Duchowny z cerkwi ze wsi Smidyn również miał wobec testatora dług w wysokości 300 zł. Iwan darował mu połowę tego zobowiązania, aby w zamian „respektem nabożeństwa” za jego duszę „słowem kapłańskim odprawował ile mógł". Opiekunowie testamentu Ihnatowicza - burmistrz Jan Wasilewicz, ktytor $^{75}$ cerkwi sobornej Teodor Hrehorowicz, diakon Jan i brat Gabriel — zostali zobligowani do sprzedania dóbr po zmarłym i przekazania uzyskanych pieniędzy pięciu miejscowym kapłanom, bakałarzowi i pałamarzowi ${ }^{76}-60$ zł na nabożeństwa za duszę zmarłego (sorokoust) i w tym samych celu 40 zł klasztorowi mileckiemu, a po 15 zł dwóm szpitalom, żeby mieszkańcy tych przybytków uczestniczyli we mszach za jego duszę.

Błażej Zguba z Dubna prosił o pochowanie go w farze, której legował 300 zł, a ojcom bernardynom 100 zł; kwoty te miał przekazać zadłużony u niego Andrzej Żółkiewski (1650 r. $)^{77}$. Katarzyna Wietrowna, spisując ostatnią wolę (w 1667 r.) wzmiankuje dłużnika swego zmarłego ojca - młynarza Macieja, który także zmarł, nie oddawszy jej kwoty 60 zł. Dług ten przeszedł na syna młynarza. Kobieta, nakazując mu zwrot pieniędzy, podzieliła je na trzy części, które miały być następująco rozdysponowane: 20 zł dla bractwa Różańca Najświętszej Panny Marii w ołyckim kościele św. Trójcy, 20 zł dla szpitala ubogich, gdzie wówczas sama mieszkała, oraz 20 zł dla cechu szewskiego. Ta ostatnia suma miała stanowić zwrot pożyczki zaciągniętej jeszcze przez ojca Katarzyny ${ }^{78}$. Szewc ołycki Matiasz Olszewski zdecydował, aby przekazać na ozdobę obrazu Różańca Najświętszej Panny Marii w miejscowym kościele św. Trójcy zastawione przez siebie cenne przedmioty: „srebra zlewanego łotów siedm i szmatę proby siódmej, które jest w zastawie w złotym jednym i groszy czterech u niewiernego Charza Hajki, Żyda ołyckiego, to taż jego małżonka Zofia wykupiwszy od tegoż Żyda odda” (1661 r.) $)^{79}$. Na końcu testamentu Jana Kozłowskiego z Kowla (1678 r.) zamieszczono adnotację: ,po napisaniu tego testamentu pr[z]ypomniał sobie p. Jan Kozłowski dług zł. 20 i pułtrzecia winny u Jacka Czerkisa, który dług przekazuje na gruntach na cerkiew św. Błagowieszczeńską i tymże testamentem realnie leguje i odkazuje na tych że gruntach Jacka Petrowicza Czerkisa"80.

Testamentarne dyspozycje funeralne polegające na przekazywaniu gotówki na instytucje kościelne przeważnie nie miały charakteru realnego ich wsparcia, gdyż były to niewielkie kwoty, które mogły jedynie pokryć koszty związane z ceremonią pogrzebową i msze za dusze zmarłych. W większości takie datki czyniła drobna szlachta, a także średniozamożni i ubodzy mieszczanie ${ }^{81}$. Brak zapisów gotówkowych niektórzy testatorzy kompensowali darowiznami w innej formie.

\section{Legaty w formie ruchomości i nieruchomości}

W przeanalizowanych testamentach mieszczan wołyńskich odnaleziono blisko 20 wzmianek o przekazywanych instytucjom religijnym i dobroczynnym ruchomościach. Były to kosztowne naczynia, obrazy, książki, kobierce, ale także żywność oraz zwierzęta hodowlane.

${ }^{74}$ CPAHUK. Z. 35, op. 1, sygn. 10, k. 105-105v.

${ }^{75}$ Ktytor (ukr. кmumop, grec. $\kappa \tau \dot{\tau} \tau \omega \rho$ — budowniczy, założyciel) — osoba, która wyłożyła fundusze na budowę albo dekorację świątyni prawosławnej.

${ }^{76}$ Pałamarz (ukr. паламар, starogrec. $\pi \alpha \rho \alpha \mu о v \alpha \rho ı \varsigma$ ) — duchowny Kościoła prawosławnego, który zajmuje się dzwonieniem, śpiewaniem i pomaganiem podczas odprawianych nabożeństw.

77 CPAHUK. Z. 33, op. 1, sygn. 6, k. 199.

78 CPAHUK. Z. 1237, op. 1, sygn. 7, k. 160.

${ }^{79}$ CPAHUK. Z. 1237, op. 1, sygn. 7, k. 58v.

${ }^{80}$ CPAHUK. Z. 35, op. 1, sygn. 6, k. 179.

${ }^{81}$ Zielecka-Mikołajczyk W. 2012, s. 142. 
I tak np. łucki mieszczanin Jan Fedorowicz dostał w spadku od prababki Jowchimii Truszowej Czajczanki kilka cennych przedmiotów (dwa srebrne pasy — jeden „złocisty tugowany”, drugi ,puklasty biały” — oraz cztery półmiski i kufel cynowy), które przekazał na rzecz nieukończonej cerkwi Przenajświętszej Bogarodzicy Pokrowskiej (1660 r. $)^{82}$. Rajca z Ołyki, Walenty Żębecki, oddał miejscowej świątyni „xięgi zaś do śpiewania należące wszystkie aby do kościoła tutejszego oddanę byli” (1654 r.) ${ }^{83}$. Wspomniana wcześniej Katarzyna Wietrowna, umierając w biedzie w ołyckim szpitalu na Zawrociu, prosiła o pochówek na cmentarzu przy starym kościele. Chciała, by po śmierci ubrano ją w jej własny kabat, chustę i pończochy, zaś aby należący do niej kożuch stary i suknię ,ppaklakową lazurową przetartą” oddano instytucji, w której przebywała pod koniec życia ${ }^{84}$. Z kolei Fruzyna Mądrzejowska ofiarowała dubieńskiej farze krowę z cielęciem, a tamtejszym oo. Bernardynom plac (1684 r. $)^{85}$.

Nieruchomości były legowane łącznie w 15 spośród badanych testamentów. Należały one do mieszczan o różnej zasobności. Przywoływana powyżej Zofia Kunowska (w 1667 r.), oprócz sporych legatów gotówkowych pozostawiła również sad z ogrodem dwóm ołyckim szpitalom wielkiego św. Krzyża i nowo fundowanemu, zlokalizowanemu na Zawrociu, pod wezwaniem św. Trójcy. Z kolei pustym placem obdarowała szpital św. Ducha, ,,aby ubodzy tych wszystkich trzech szpitalów Pana Boga przy aniwersarzu się rocznym odprawującym, obecnie będący i mszej świętej słuchający prosili”. Testatorka zapisała także drewnianą komorę (magazyn) znajdującą się przy ratuszu (a zarazem naprzeciwko murowanych komór) dla nowego kościoła ołyckiego, „na altarją dla odprawowania czterech mszy czytanych po jednej na kwartał” za dusze jej samej i jej pierwszego małżonka ${ }^{86}$. Z kolei dubieński mieszczanin, Zacharjasz Żydkiewicz, legował sad „wielebnym ojcom” z mileckiego klasztoru, aby za jego duszę „Pana Boga prosili i sorokoust odprawili” (1686 r. $)^{87}$. Mieszczka ołycka Ewdoksia Iwanowa Kapitanicha zapisała na rzecz zawrockiej cerkwi „dninę” pola bez zasiewu, a drugą „dninę” pola dla protopopa ołyckiego, z intencją, ,żeby ciało jej pochował, w sobotnik wpisał i czterdzieści mszy świętych odprawił, i wszystko co należy do zbawienia duszy jej uczynił" (1666 r. ${ }^{88}$. Fedora Makarowna Carowa chciała być pochowana na cmentarzu przy tej cerkwi, której podarowała „dninę” pola, wykupioną za 40 zł u Jaśka Żołnierka. Była przekonana, że dzięki temu uratuje swą duszę: „A z tej legatiej po pogrzebie odprawionym, aby mnie w sobotnik wpisano, stoły odprawiono i za duszę moją dobrze zawsze czyniono. [...] dninę pola odkazuję do cerkwie pomienionej na ozdobę wszelką według upodobania panów starszych i przełożonych cerkwi świętej, aby dusza moja zawsze miała na tamtym świecie ochłodę i pociechę" (1666 r. $)^{89}$. Katarzyna Lewkowa Hrebtunowa z Dubna zapisała połowę włóki pola szpitalowi ruskiemu w zamian za złożenie jej ciała na nekropolii przy cerkwi św. Eliasza. Na rzecz tej świątyni ofiarowała także pieniądze uzyskane ze sprzedaży połowy należącego do niej domu $(1674 \mathrm{r} .)^{90}$. Małżonkowie z Włodzimierza, Jan Nazarowicz i Krystyna Rusakowna, spisali testament podczas panującej w mieście morowej zarazy (w 1652 r.), zapisując wówczas wszystkie ruchomości oraz folwarki o wartości $50 \mathrm{zł} \mathrm{tamtejszej} \mathrm{cerkwi} \mathrm{św.} \mathrm{Dwunastu} \mathrm{Apostołów}{ }^{91}$. Były żołnierz, Marcin Chmielowski, umierając przeznaczył ,[...] dom własny, leżący [w Kowlu — N.B.] na

${ }^{82}$ CPAHUK. Z. 2073, op. 1, sygn. 43.

${ }^{83}$ CPAHUK. Z. 1237, op. 1, sygn. 4, k. 40.

${ }^{84}$ CPAHUK. Z. 1237, op. 1, sygn. 7, k. 160.

${ }^{85}$ CPAHUK. Z. 33, op. 1, sygn. 10, k. 10v.

${ }^{86}$ CPAHUK. Z. 1237, op. 1, sygn. 7, k. 158v.

${ }^{87}$ CPAHUK. Z. 33, op. 1, sygn. 10, k. 20.

${ }^{88}$ CPAHUK. Z. 1237, op. 1, sygn. 7, k. 153.

${ }^{89}$ CPAHUK. Z. 1237, op. 1, sygn. 7, k. 150.

${ }^{90}$ CPAHUK. Z. 33, op. 1, sygn. 1, k. 464-465.

${ }^{91}$ CPAHUK. Z. 28, op. 1, sygn. 89, k. 491v. 
ulicy przed zamkiem, w ni w czym nikomu nie zawiedziony”, na szczególny cel: „Tedy ten dom [...] oddaję na szpital aby dla ubogich starych, okaleczonych w wojsku był ten dom wygodą" (1665 r.). Jako wykonawców swej ostatniej woli, gwarantujących urzeczywistnienie tych decyzji, wskazał: trębacza wojsk JKMci Mikołaja Nitwiskiego, landwójta Grzegorza Dobrostańskiego oraz dwóch burmistrzów Andrzeja Znojowskiego i Marka Nifanowicza ${ }^{92}$.

\section{Legaty na inne cele}

Tylko sporadycznie czyniono legaty o charakterze precyzyjnych dyspozycji (odnotowano je w 22 analizowanych testamentach). K. Mrozowski trafnie zauważył, że rzadkie stosowanie zapisów o jasno określonym celu sugeruje, że dla testatorów ważniejsze było samo złożenie ofiary, niż utrwalenie i upamiętnienie własnej osoby w fundowanym przedmiocie ${ }^{93}$. W omawianych dokumentach umieszczano zalecenia dotyczące przekazania określonej sumy na budowę albo remont (reperację) kościoła parafialnego, wykonanie dla niego konkretnego przedmiotu liturgicznego bądź ozdobienie obrazu.

I tak, np. dubieńska mieszczka Regina Sokołowa ofiarowała na rzecz klasztoru bernardyńskiego, w którym pragnęła być pochowana, biały srebrny pas, zastawiony u Żyda Moszka za sumę 60 zł. Poleciła, by krewni wykupili tę kosztowną rzecz, a z uzyskanego surowca wykonali kielich dla tamtejszego kościoła. Regina przekazała także swoje korale oraz pięć czerwonych złotych do dekoracji obrazu Najświętszej Panny Marii (1650 r. $)^{94}$. Ołycki pisarz miejski Andrzej Łabuński wyraził życzenie, by z posiadanego przez niego srebra „łotów cztery, [...] tabliczka [wotywna została - N.B.] zrobiona na obraz Przenaświętszej Panny Różańcowej” do kolegiaty św. Trójcy (1660 r. $)^{95}$. „Na ozdobę” tego wizerunku Maryi miejscowy szewc Matiasz Olszewski oddał „srebra zlewanego łotów siedm i szmatę proby siódmej”96. Natomiast Jowsia Semenowa Weremiejczykowa, chociaż byłą unitką, podarowała w analogicznym celu naszyjnik prawosławnej cerkwi zalesockiej w Ołyce $(1654 \text { r. })^{97}$. Z kolei cerkiewne srebro kupione u archimandryty mileckiego klasztoru za 30 zł, wzmiankowany wcześniej Iwan Ichnatowicz przeznaczył testamentem (z 1695 r.) na wykonanie oprawy „księgi św. Ewangelii”, a dziewięć łotów srebra na podobny cel dla cerkwi sobornej w Kowlu ${ }^{98}$. Fedor Awdziejczyk z Ołyki, chcąc zaskarbić sobie Bożą łaskę, przeznaczył określoną kwotę „ku ozdobie Panny Przeczystej” w unickiej świątyni. Pieniądze miały pochodzić ze zbycia majątku, ale dopiero po śmierci dzieci Fedora. Swoje życzenie wyraził w oryginalnej formie: ,[...] upraszam wielce dla miłosierdzia Bożego sławetnych P.P. urzędowych miasta jako dobrodziejów i opiekunów wszytkich sierot, a nie tylko mych pozostałych, aby oni na nich i na dobra ich, także i na samych ich opiekunów ode mnie niżej pomienionych oko pilne mieli, aby te dobra ledajak po śmierci dziatek moich nie zniszczały, ale co by się z nich zostało ordinuję na cerkiew Świętą Zawrocką Trójce Przenaświętszej ku ozdobie Panny Przeczystej tych dobr dziesięć kop litewskich, a ostatek dobr onym krewnym ordinuję" (1667 r. $)^{99}$. Kowelski landwójt Marek Nifanowicz postanowił przekazać fundusze na renowację dwóch tamtejszych obiektów — prawosławnej cerkwi Zwiasto-

92 CPAHUK. Z. 35, op. 1, sygn. 2, k. 283.

93 Mrozowski K. 2010, s. 194.

94 CPAHUK. Z. 33, op. 1, sygn. 6, k. 157-157v.

95 Tam testator chciał być pochowany: „Ciało ziemi oddając, prosił aby było po katolicku według przemożenia małżonki swej pozostałej Reginy Miedziakowiczowny w kościele murowanym w kaplicy Różańcowej brackiej za pozwoleniem tych że P.P. braciej pochowane [zostało - N.B.]", CPAHUK. Z. 1237, op. 1, sygn. 7, k. 45v-46.

${ }^{96}$ CPAHUK. Z. 1237, op. 1, sygn. 7, k. 58v-59.

${ }^{97}$ CPAHUK. Z. 1237, op. 1, sygn. 4, k. 48.

${ }^{98}$ CPAHUK. Z. 35, op. 1, sygn. 10, k. 106-106v.

99 CPAHUK. Z. 1237, op. 1, sygn. 7, k. 162. 
wania Pańskiego (50 zł) oraz szpitala ruskiego (40 zł z pieniędzy odzyskanych od Żyda Majera Bieniaszewicza (1676 r. $)^{100}$. Jego siostra Tatiana, umierając w 1690 r., zaznaczyła w swoim testamencie, że oddała mileckiemu klasztorowi „na fundusz przez legacje nieboszczyka Marka Nifanowicza zł. 50"'101. Środki finansowe ze sprzedaży majątku po Iwanie Ichnatowiczu (1695 r.), pozostałe po realizacji wyżej wymienionych legatów zostały — zgodnie z wolą testatora — przeznaczone „na cerkiew soborną do restauracji Deisusa"102. Natomiast na odnowienie tejże cerkwi Iwan Posuszka ofiarował: „,na cerkiew Wedenowską na restauratią żyta mace ${ }^{103}$ jedną, a na dzwo[n]nicę Woskreseńską pułmace" (1686 r.). Uzasadnił swoje postępowanie troską o zbawienie swej duszy ${ }^{104}$.

Charakterystyczną formą miejskiej religijności zarówno zachodniego, jak i wschodniego obrządku, była troska o ubogich i chorych, manifestowana przez testatorów za pomocą rozmaitych legatów i zapisów ${ }^{105}$ : dla szpitali działających przy świątyniach, na budowę i remonty przytułków oraz poprzez rozdawanie jałmużny podczas pogrzebów. Testatorzy spełniali w ten sposób chrześcijański obowiązek troski o bliźnich, a w zamian zyskiwali ich modlitwy za swą duszę. Czynienie dyspozycji na rzecz ubogich w testamentach prawosławnych i unitów stało się popularne od lat czterdziestych XVII w., a praktyka ta była nadal powszechna w kolejnym stuleciu $^{106}$. Mieszkaniec Łucka Krzysztof Niemyski w swoim testamencie (z 1638 r.) prosił sukcesorów, by sprzedać należące do niego żyto i jarzyny, a z kwoty tej każdemu przebywającemu w szpitalach św. Łazarza i św. Ducha dać po 5 zł, aby modlili się za jego duszę ${ }^{107}$. Dubieńska mieszczka, Maria Seńkowna, legowała na tamtejsze szpitale — polski i ruski po 5 zł $(1645 \text { r. })^{108}$. Ołycki murarz Michał Walda zapisał 130 zł na szpital św. Krzyża w Ołyce, ,aby co rok msza święta czytana odprawowała się za duszę testatora. $Z$ tegoż wyderkafu obiad ubogim sprawić będzie powinien ten, kto będzie tę pieniądze lubo włókę trzymał, a ubodzy mszę świętej słuchać powinni" ${ }^{\prime 109}$. Dorota Jakubowa Grochowalska przekazała na rzecz tej instytucji 100 zł, którą to sumę oddała księdzu Stanisławowi Dzierzkowi, kanonikowi ołyckiemu i prowizorowi szpitala, za co otrzymała kwit; wspomniała o tym w swoim testamencie (z 1668 r. $)^{110}$. Paweł Niczyporowicz, umierając w 1668 r. w domu ołyckiej mieszczki Katarzyny Toczewickiej prosił, aby sprzedać jego nową, białą siermięgę i uzyskane tym sposobem pieniądze oddać cerkwi zawrockiej, zaś starą białą siermięgę oddać ubogim w szpitalu funkcjonującym przy tej świątyni ${ }^{111}$. Z kolei Błażej Zguba zapisał szpitalowi w Dubnie kwotę 26 zł i „rzeczy ruchome wszytkie”, czyli różne części odzieży: ,jako żupan stary, koszul trzy i spodnich troje, kożuch”, natomiast „koc także — ten [oddał dla — N.B.] subdjakonu kościoła farskiego"112.

${ }^{100}$ CPAHUK. Z. 35, op. 1, sygn. 6, k. 13-15.

101 CPAHUK. Z. 35, op. 1, sygn. 9, k. 74.

102 CPAHUK. Z. 35, op. 1, sygn. 10, k. 106-106v.

${ }^{103}$ Maca - miara objętości ciał luźnych, była równa 80-100 kilogramów (litrów).

104 „Duszę moję niepodległe skazytelności jako od Najwy[ż]szego Stwórcy w ciało moje włożone, temu wszechmogącemu Stwórcy w ręce poruczam, prosząc miłosierdzia Pańskiego, aby był miłosierdnym nad ciałem i duszą moją, i aby mnie według występków mych nie raczył karać, ale duszę moje raczył zbawić. Ciało moje według porządku chrześci[j]ańskiego aby w cerkwi świętej Wedenowskiej było pochowane. Za duszę moje wszelkie obrzędy cerkiewne z dóbr moich tak małżonki, jako i dzieci moje mają dosyć uczynić aż do dorocznej odprawy", CPAHUK. Z. 35, op. 1, sygn. 8, k. 16-17.

105 Mrozowski K. 2010, s. 195.

106 Zielecka-Mikołajczyk W. 2012, s. 161-163.

107 CPAHUK. Z. 23, op. 1, sygn. 1, k. 31.

108 CPAHUK. Z. 33, op. 1, sygn. 6, k. 16v.

109 CPAHUK. Z. 1237, op. 1, sygn. 4, k. 83v.

${ }^{110}$ CPAHUK. Z. 1237, op. 1, sygn. 7, k. 170-170v.

111 CPAHUK. Z. 1237, op. 1, sygn. 7, k. 175v.

112 CPAHUK. Z. 33, op. 1, sygn. 6, k. 199. 
W omawianych testamentach zarejestrowano również ciekawe zapisy na rzecz pobliskich wiejskich parafii. Występowanie takich legatów tłumaczy się na ogół przywiązaniem testatorów do rodzinnych stron ${ }^{113}$. I tak, śmiertelnie chora Uksinja Iwanowa prosiła kapłana z surmickiej cerkwi w Dubnie - ojca Michajła, aby pochował ją nie w tej miejscowości, lecz przy cerkwi św. Cudotworców Koźmy i Damiana we wsi Ratczyn, gdzie się urodziła. Testatorka zobowiązała egzekutorów do sprzedania jej dóbr i przekazania pieniędzy na rzecz owej świątyni (1649 r.). Rok po jej śmierci w kancelarii dubieńskiego magistratu na końcu testamentu dopisano, że ze sprzedaży rzeczy po zmarłej otrzymano kwotę 90 zł: „za którą to summę Kondrat i Hrehory kupili do cerkwi Bożej Koźmy i Demiana aparaty, naprzód filon adamaszkowy czerwony, petrachil adamaszkowy czerwony, narakwicy adamaszkowe czerwone, wozduch hatłasowy zielony, wozduszek mały adamaszkowy czerwony"114. Takie darowizny były ważne dla funkcjonowania lokalnych ośrodków religijnych.

\section{Podsumowanie}

Wysokość kwot zapisywanych w testamentach, świadczących o przywiązaniu do określonego kultu, kościoła lub klasztoru pozwala nam w pewnym stopniu zrekonstruować świat mieszczańskich wierzeń i wartości, badać stosunek testatora do różnych instytucji religijnych oraz pobożność ówczesnych ludzi. Oczywiście znaczne darowizny na odprawiane msze, na Kościół lub szczodre dotacje na Cerkiew dokonywane w testamencie nie zawsze oznaczały, że testator był przez całe życie osobą praktykującą i głęboko wierzącą. Z drugiej strony, brak legatów na cele pobożne lub charytatywne nie oznacza braku szacunku wobec instytucji religijnych.

W omawianych siedemnastowiecznych testamentach mieszczan wołyńskich czasami nie ma arengi, w której testator zwykle wypowiadał się na temat marności, kruchości życia ludzkiego itd., albo jest ona zredukowana do jednego zdania (co cechuje testamenty z XVI w.). Generalnie spośród analizowanych 140 testamentów tylko 50 (czyli 36\% ogółu) zawiera informacje o legatach dobroczynnych i religijnych, tzn. prawie $2 / 3$ wszystkich testatorów nie uczyniło żadnego zapisu na te cele ${ }^{115}$. Może się to wydawać zaskakujące. W przypadku zachowania większego zbioru tej kategorii źródeł, proporcje te przypuszczalnie wyglądałyby nieco inaczej. Natomiast na podstawie zachowanych materiałów można jedynie domniemywać, że wynikało to częściowo z ubóstwa testatorów, z posiadania przez nich licznych spadkobierców (zwłaszcza małych dzieci), albo także z powodu obciążenia testatorów licznymi długami. W wielu przypadkach spisujący swoją ostatnią wolę (przeważnie prawosławni) wyrażali przekonanie, że ich sukcesorzy zatroszczą się o ich duszę i pochówek oraz według „swego baczenia” przekażą fundusze na ,pobożne uczynki”.

Polscy i ukraińscy badacze zaznaczają, że w XVII w. średniozamożni testatorzy byli najbardziej związani z lokalnymi świątyniami, czyniąc przede wszystkim donacje na rzecz tych, które miały się stać miejscem pochówku oraz odprawiania mszy za zbawienie ich duszy. Halina Manikowska uważa, że w legatach na rzecz Kościoła widoczne jest również osobiste przywiązanie do jego określonych instytucji, a także potrzeba zapewnienia sobie jakiejś formy trwania w życiu miejskiej wspólnoty nawet po śmierci ${ }^{116}$. Według Wioletty Zieleckiej-Mikołajczyk, w ciągu badanego stulecia następuje zmiana w doborze obdarowywanych instytucji oraz wielkości zapisów na poszczególne ośrodki cerkiewne. Mianowicie członkowie Kościoła unickiego bez względu

113 Mrozowski K. 2010, s. 194.

114 CPAHUK. Z. 33, op. 1, sygn. 6, k. 195-195v.

115 Dla porównania: według obliczeń E. Piwowarczyk, w późnośredniowiecznym Krakowie średnio dwie trzecie spośród testatorów dokonywało zapisów na dzieła pobożne w ostatnim rozporządzeniu swej woli, ale zapewne wielu z nich uczyniło to jeszcze za swojego życia, zob.: Piwowarczyk E. 2013, s. 430.

116 Manikowska H. 2002, s. 26. 
na stan zamożności czynią zapisy na cerkwie, klasztory unickie i kościoły rzymskokatolickie. Prawosławni ofiarowują pieniądze przeważnie na cerkwie w swoim obrządku, a od lat sześćdziesiątych wzrasta liczba zapisów na cerkwie unickie ${ }^{117}$. Wydaje się, że podobna sytuacja była charakterystyczna także dla społeczności miejskiej Wołynia w omawianym okresie.

Wysokość opisywanych legatów mieszczan wołyńskich to najczęściej nieduże kwoty (głównie 5-10 zł polskich), nieodzyskane za życia wierzytelności lub pieniądze, które miały być wypłacone przez spadkobierców w zamian za przekazany majątek. Największe kwoty 200-300 zł legowały zamożne mieszczki wyznania katolickiego, zwłaszcza w Ołyce. W miastach koronnych, jak wynika ze sformułowań zawartych w zachowanych testamentach, ,zbawieniem duszy" bardzo przejmowały się bogate katoliczki, o czym świadczą zapisane przez nie duże sumy przeznaczone na pochówek i na rozmaite cele pobożne ${ }^{118}$. Różnica polegała na wysokości darowizn. Według spostrzeżeń Bożeny Popiołek, wysokość legatów zależała wyłącznie od zamożności i dobrej woli testatora, zdarzały się też darowizny w naturze — zbożu, zwierzętach hodowlanych, miodzie lub tekstyliach — które trudno oszacować, ale takie zapisy stanowiły niekiedy znaczącą pomoc dla szpitali lub przytułków ${ }^{119}$. Podobnie w miastach wołyńskich najwięcej było darowizn w naturze, ale także w formie różnych mobiliów i nieruchomości. Testatorzy kierowali się przy tym przekonaniem, że pomoc instytucjom religijnym może pomóc duszy człowieka. W analogicznym celu dokonywali również zapisów na msze zaduszne, zlecając dopilnowanie ich realizacji spadkobiercom lub egzekutorom. Obdarowywali również działające przy kościołach i cerkwiach szpitale, praktykowali udzielanie jałmużny podczas uroczystości pogrzebowych. W ten sposób, wykazując troskę o bliźnich, zapewniali sobie ich modlitwy. Omawiane dyspozycje dobrze wpisują się w obyczajowość religijną i testamentową ówczesnej Rzeczypospolitej.

Adres Autorki:

dr Natalia Biłous

Instytut Historii Ukrainy Narodowej Akademii Nauk Ukrainy

ul. M. Hruszewskiego 4

Kijów 01001

Ukraina

bilnat2009@gmail.com

https://orcid.org/0000-0002-6036-3204

\section{BIBLIOGRAFIA}

\section{Źródła archiwalne:}

CPAHUK [Centralne Państwowe Archiwum Historyczne Ukrainy w Kijowie], zesp. 23, sygn. 1; zesp. 25 , sygn. 103, 160, 183; zesp. 26, sygn. 31 ; zesp. 28, sygn. 89; zesp. 33, sygn. 1, 6, 10; zesp. 35, sygn. 2, 4, 6, 7, 8, 9, 10; zesp. 1237, sygn. 1, 4, 7; zesp. 2073, sygn. 43.

LNNB [Lwowska Naukowa Biblioteka im. Wasyla Stefanyka], zesp. 91 [Radzimińskie], sygn. 44.

\section{Źródła i opracowania publikowane}

Arkhiv ukrains'koi tserkvy. 2014. Arkhiv ukrains'koi tserkvy, seriia 2. Dzherela, vyp. 1. Istoriia Luts'koho bratstva i brats 'koho monastyria 1617-1833, wyd. M. Dovbyschenko, Luts'k.

Biłous Natalia. 2016. Testament ostroz'koho i dubens 'koho mischanyna Oleksandra Dzusy 1667 r., Ostroz'ka davnyna, t. 5, red. I. Pasichnyk, I. Teslenko i in., Ostrih, s. 73-79.

117 Zielecka-Mikołajczyk W. 2012, s. 151-152; 2009, s. 231-250.

118 Zob. np.: Oliński P. 1998, s. 143-160; Pelczar R. 2006, s. 95-112; Karpiński A. 2011, s. 363-378.

119 Popiołek B. 2009, s. 174. 
Biłous Natalia. 2017. Testamenty mieszkańców miast Wolynia od końca XVI-do poczatku XVIII wieku. Katalog, Warszawa.

Dovbyschenko Mychajło. 2008. Volyns 'ka shliakhta u relihijnykh rukhakh (kinets' XVI-1 pol. XVII cm.), Kyiv.

Yakovenko Natalia. 2012. „Osvoienyj prostir”: mistsia pokhovan 'volyns 'koi shliakhty (ser. XVI-ser. XVII st.), [w:] Od Kijowa do Rzymu. Z dziejów stosunków Rzeczypospolitej ze Stolica Apostolska $i$ Ukraina. W 35-lecie pracy naukowej T. Chynczewskiej-Hennel, red. M. Drozdowski i in., Białystok, s. 137-152.

Horin Serhij. 2009. Zapovity iak dzherelo doslidzhennia istorii monastyriv Volyni XVI-pershoi polovyny XVII st., Naukovi zapysky. Zbirnyk prats' molodykh vchenykh ta aspirantiv, t. 19, Kyiv, s. $19-35$.

Horin Serhij. 2011. Dubens'ki Voznesens'kyj, Spasopreobrazhens 'kyj i Khrestovozdvyzhens'kyj monastyri (do seredyny XVII st.), Drohobyckij krajeznavchyj zbirnyk, t. 14-15, Drohobych, s. $133-158$.

Karpiński Andrzej. 1989. Zapisy pobożne i postawy religijne mieszczanek polskich $w$ świetle testamentów z drugiej połowy XVI i XVII w., [w:] Tryumfy i porażki. Studia z dziejów kultury polskiej, red. M. Bogucka. Warszawa, s. 204-232.

Karpiński Andrzej. 2011. Dobroczynne i religijne legaty lwowskich mieszczan w świetle ich testamentów z lat 1550-1700, „Kwartalnik Historii Kultury Materialnej”, R. LIX, nr 3-4, s. 363-379.

Kempa Tomasz. 2011. Fundacje monasterów prawosławnych w Rzeczypospolitej w pierwszej połowie XVII w., [w:] Życie monastyczne w Rzeczypospolitej, red. A. Mironowicz, U. Pawluczuk, P. Chomik, Białystok, s. 74-102.

Krochmal Jacek. 1989. Przemyskie testamenty staropolskie, „Rocznik Historyczno-Archiwalny”, t. VI, s. $133-160$.

Kubicki Rafał. 2011. Formy pobożności w mieście średniowiecznym w świetle zapisów na rzecz kościoła i biednych $w$ testamentach elbląskich (koniec XV-pocz. XVI wieku), „Zapiski Historyczne", t. 76, z. 2, s. 7-27.

Manikowska Halina. 2002. Religijność miejska, [w:] Ecclesia et civitas. Kościót i życie religijne w mieście średniowiecznym, red. H. Manikowska, H. Zaremska, Warszawa, s. 11-34.

Mironowicz Andrzej. 1999. Działalność charytatywna w Kościele Prawosławnym na terenie Rzeczypospolitej w XVI-XVIII wieku, [w:] Charitas. Miłosierdzie i opieka spoleczna w ideologii, normach postępowania i praktyce społeczności wyznaniowych w Rzeczypospolitej XVI-XVIII w., red. U. Augustyniak, A. Karpiński, Warszawa, s. 79-86.

Mrozowski Krzysztof. 2010. Religijność mieszczan późnośredniowiecznej Warszawy w świetle najstarszych zachowanych testamentów, „Kwartalnik Historii Kultury Materialnej”, R. LVIII, nr 2, s. 191-196.

Nowak Alicja Z. 2008. Testament - integralna część przygotowań do dobrej śmierci w refleksji prawosławnego kręgu kijowskiego XVII w., „Kyivs'ka Akademiia”, t. 6, s. 48-62.

Oliński Piotr. 1998. Fundacje i legaty religijne kobiet świeckich $w$ wielkich miastach pruskich, [w:] Kobieta i rodzina w średniowieczu i na progu czasów nowożytnych, red. Z. Nowak, A. Radzimiński, Toruń, s. 143-160.

Oliński Piotr. 2008. Fundacje mieszczańskie w miastach pruskich w okresie średniowiecza i na progu czasów nowożytnych (Chetmno, Toruń, Elblag, Gdańsk, Królewiec, Braniewo), Toruń.

Pelczar Roman. 2006. Działalność dobroczynna właścicielek Jarosławia dla Kościoła rzymskokatolickiego w II połowie XVI-I połowie XVII w., [w:] Kobiety i kultura religijna. Specyficzne cechy religijności kobiet w Polsce, red. J. Hoff, Rzeszów, s. 95-112.

Piwowarczyk Elżbieta. 2010. Legaty testamentowe ad pias causas w XV-wiecznym Krakowie. Z badań nad pobożnościa miejską, Kraków.

Piwowarczyk Elżbieta. 2011a. Jałmużna na biednych i chorych w szpitalu Świętego Ducha w Krakowie wyrazem późnośredniowiecznej troski o dobro wspólne, „Rocznik Krakowski”, t. 77, s. 15-34.

Piwowarczyk Elżbieta. 2011b. Pobożność krakowskich mieszczan w świetle ich testamentowych legatów z lat 1501-1530, „Saeculum Christianum”, t. 18, z. 2, s. 77-100. 
Piwowarczyk Elżbieta. 2013. Wnioski badawcze w zakresie legatów testamentowych ad pias casusas $w X V$-wiecznym Krakowie, [w:] Habent omnia tempora sua. Prace ofiarowane ks. prof. dr. hab. Januszowi Wyciśle, red. Z. Gogola, Kraków, s. 415-430.

Popiołek Bożena. 2009. „,Woli mojej ostatniej testament ten...” Testamenty staropolskie jako źródto do historii mentalności XVII i XVIII wieku, Kraków.

Popruzhna Ałła. 2006. Dukhovni zapovity iak dzherelo z istorii blahodijnytstva kozats'koi starshyny, [w:] Materialy nauk. konf. „,Kul'turno-relihijnyj rozvytok Het'manschyny kintsia XVII-poch. XVIII cm.", Nizhyn, s. 171-175.

Tymoszenko Leonid. 2011. Tradytsiia i praktyky pomynannia pomerlykh u Kyivskii mytropolii v druhii polovyni XVI-pershii polovyni XVII st vnesok tserkovnykh bratstv, [w:] Drohobyts 'kyj kraieznavchyj zbirnyk, Vyp. 14-15, Drohobych, s. 116-132, http://shron1.chtyvo.org.ua/ Tymoshenko_Leonid/Tradytsiia_i_praktyky_pomynannia_pomerlykh_u_Kyivskii_mytropolii_v_druhii_polovyni_XVI_pershii_polovyni_XVII_st_vnesok_tserkovnykh_bratstv.pdf.

Vinnychenko Oksana. 2010. Pobozhni zapysy i poriatunok dushi v mental'nosti rann'omodernoi liudyny na materiialakh shliakhets 'kykh zapovitiv pershoi polovyny XVIII st., Naukovi zapysky Ukrains'koho katolyts'koho universytetu. Chyslo II. Seriia Istoriia, vyp. 1, L'viv, s. 51-65.

Vinnychenko Oksana. 2014. „Poriatunok dushi” u svitli testamentiv l'vivs 'kykh virmen XVII-XVIII cm., [w:] Lwów: miasto — społeczeństwo — kultura. Studia z dziejów miasta, t. IX: Życie codzienne miasta, red. K. Karolczak, Ł.T. Sroka, Kraków, s. 73-83.

Vinnychenko Oksana. 2017. Katolyky ,, virmens "koi natsii”: transformatsiia konfesijnoi identychnosti l'vivs "kykh virmen pislia ukladennia unii z Rymom (za materialamy testamentiv XVII-I polovyny XVIII st.), [w:] Przemiany polityczno-ustrojowe, gospodarczo-społeczne, kulturalnoreligijne $w$ prowincji małopolskiej $w$ epoce nowożtnej. Polsko-ukraińskie sympozja epoki nowożytnej. Kraków 8-10.11.2017, red. W. Michałowski, J. Stolicki, Kraków.

Wiadomość. 1899-1900. Wiadomość o profesorach Akademii Zamojskiej, wyd. J.A. Wadowski, Warszawa.

Zielecka-Mikołajczyk Wioletta. 2009. Formy aktywności religijnej prawosławnych i unitów z terenów Wielkiego Księstwa Litewskiego i ziem ruskich Korony w świetle testamentów (XVI-XVIII w.), [w:] Studia z dziejów i tradycji metropolii kijowskiej XII-XIX wieku, red. A. Gil, Studia i materiały do dziejów chrześcijaństwa wschodniego w Rzeczypospolitej, t. 5, Lublin, s. 231-250.

Zielecka-Mikołajczyk Wioletta. 2012. Prawosławni i unici w Rzeczypospolitej XVI-XVIII wieku wobec życia i śmierci w świetle testamentów, Warszawa.

Charity bequests and legacies to churches of various denominations in 17th-century testaments of Volhynian burghers

Volhynian testaments from the 17 th $\mathrm{c}$. are a valuable source for research on burghers' religiousness and piety. In the 140 available last wills that were analysed for the purpose of the present article only 50 (i.e. $36 \%$ ) included charitable and religious bequests, which means that almost $2 / 3$ of the testators did not make any such bequests. The analysed documents suggest that this happened when testators were not rich, had numerous heirs (especially young children) or left many debts to be settled. Many testators (especially those belonging to the Orthodox Church) expressed their certainty that the heirs would take care of their funeral and salvation, and would donate some funds for charitable purposes at their own discretion.

Volhynian burghers were mostly attached to local churches and made bequests to those in which they wanted to be buried and have masses said for their salvation. The bequests were usually small sums (5-10 Polish zloties), debts collectable from third parties, or money that was to be paid by heirs in exchange for some property transferred to them. The largest bequests (200-300 Polish zloties) were made by rich Catholic women. The most common forms were 
legacies in kind (wheat, food, livestock), movables (valuable vessels, paintings, books, tapestries, garments) and immovables (houses, farmland, meadows, orchards).

Testators followed the assumption that their support of religious institutions might help their salvation. With the same intention they bequeathed money for masses for their souls, asking heirs or executors to make sure they would be said. They also left legacies to hospitals run by Catholic or Orthodox churches, supported the poor, or gave alms at funerals, thus fulfilling the Christian duty to help others and deserving their prayers. Such bequests were significant for the functioning of local religious institutions.

The bequests discussed in this article are symptomatic of both testamentary and religious customs of the Polish-Lithuanian Commonwealth.

Proofread by

Izabela Szymańska 